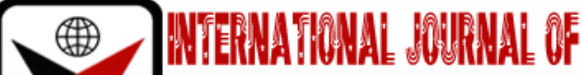

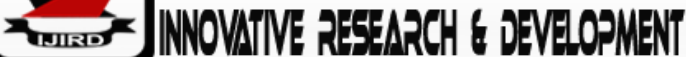

ISSN 2278-0211 (Online)

\section{Managing Overcrowded Classrooms to Accommodate Learner Centered Methodologies: An Indispensable Pillar for Teachers' Preparedness in Implementation of Competency- Based Curriculum in Kenya}

Wilbrodah Adhiambo Orina
Doctoral Student, Department of Postgraduate Studies in Education (Research and
Evaluation), Catholic University of Eastern Africa (CUEA), Nairobi, Kenya
Dr. Susan Macharia
Senior Lecturer Department of Postgraduate Studies in Education (Research and
Evaluation), Catholic University of Eastern Africa (CUEA), Nairobi, Kenya
Dr. Elizabeth Ngozi Okpalaenwe
Lecturer, Department of Postgraduate Studies in Education (Research and Evaluation),
Marist International University College, Nairobi, Kenya

\begin{abstract}
:
The implementation of the Kenyan Competency-Based Curriculum has faced a myriad of challenges. While most scholars do not cite overcrowding as a major problem facing publicacademic institutions, issues like quality of education, teacher-student ratio, lack of facilities, can be traced to some extent tothe high learner population. The objective of this study was to assess teacher preparedness in execution of science learning areas in the Kenyan Competency-Based Curriculum. Social Constructivist theory and the Trans-theoretical Model underpinned the study while offering alternatives that may be useful in decongesting the already crowded public schools in Kenya. The study adopteda concurrent triangulation design, mixing survey data with qualitative data from structured interviews and desktop research. The study targeted two hundred and three public primary schools in Nairobi County (N=203) and randomly sampled 324 teachers. The study's unexpected finding was that public primary schools in Nairobi County were too crowded to support a learner-centered approach which is central to the successful quality implementation of the Competency-Based Curriculum in Kenya. At the same time, the study connotes that low-cost private schools have been observed to be slowly shutting down in several parts of Kenya which has left teachers without a source of livelihood. Unutilized teacher potential and wasted education structural resources have been the result. The study recommends introducing charter schools at the primary level and funding low-cost private schools to accommodate excesses in public schools. The gist of it is to enable teachers handle smaller numbers that will accommodate LearnerCentered Learning Methodologies for effective quality implementation of the Competency Based Curriculum.
\end{abstract}

Keywords: Charter schools, competency based curriculum, learner centered learning, overcrowded classrooms, public primary schools

\section{Introduction}

Overcrowding in Kenyan public schools has been an issue of great concern to stakeholders in the education sector. Overcrowding is an outcome of various factors such as the $100 \%$ transition policy, increased learners' population, shortage of teachers, limited funding for structural expansion, and the school construction policy. While some scholars do not cite overcrowding as a major problem facing public primary schools and other academic institutions, other issues, including low quality of education, unsatisfactory teacher-to-student ratio, hastily and poorly constructed physical facilities as well as learner under-achievement can be traced to high student population (Hachem \& Mayor, 2019). This paper is a presentation of findings of high number of learners in CBC classes which then is a hindrance to adoption and execution of learner centered methodologies by teachers.

\section{Theoretical Review}

This study was underpinned by the Social Constructivist Theory propounded by John Dewey around 1916. Constructivism is a learning theory that postulates that through experiencing phenomena, individuals construct and shape knowledge in many different ways (Fernando \&Marikar, 2017). The core concept of this theory provides that learning is an active process and takes place better when the learner is an active constructor of knowledge in the learning process rather 
than a passive recipient of the knowledge transmitted by the instructor (Williams, 2017). In this approach, the learner participates through designing problems, constructing solutions, grading the answers, assessing outcomes, disputing and correcting results; and discussing the challenges in what is referred to as participatory teaching and learning (Fernando \&Marikar, 2017).

Constructivists also maintain that learning would take place effectively where learners have the benefit of observing all learning activities being carried out by their peers. Thus, constructivist teaching and learning theory advocates participatory or rather learner-centered learning, which is impossible for an instructor to monitor in a crowded classroom (Education Commission of the States, 2020). As such, this theory implies that small size classrooms would be more effective than larger ones in the sense that each individual learner gets services from the teacher and, methodologies such as small group activities, learning by play, doing simple projects in groups, and learning through different stations in classrooms are a possibility.

\subsection{Trans-theoretical Model}

The Trans-theoretical Model offers those changes to behavior and patterns that involve six-stage progressive changes: Pre-contemplation stage, contemplation stage, preparation level, action stage, maintenance stage, and termination stage (Prochaska \& Velicer, 1997). The theory has been used to successfully reduce homelessness in lowincome populations (Campbell, 2006). Japan relied on the Trans-theoretical model to offer a settlement for the homeless population. As a result, Japan currently has the least homeless people globally(Yi, 2020). Furthermore, the theory will be instrumental in managing the overcrowded classrooms in public schools to accommodate students from low-income families as applied in Campbell (2006).

The 8-4-4 system that is being faced out in Kenya faced challenges of overcrowding in classes the moment Free Primary Education policy was enforced. This has moved from bad to worse for the Kenyan public school classroom since the implementation of the $100 \%$ transition policy was implemented. Education Commission of the States (2020) offers that an ideal classroom should have 15- 20 learners. Any ratio of teacher to learners above 1:25 means that learners are passive participants and gain less from a session. Be that as it may, the majority of classrooms in Kenyan public primary schools have more than 50 learners. In the Kenyan new curriculum dispensation, majority of the CBC classrooms have high enrolment of learners(Mutisya, 2020). Congestion is extreme in marginalized environments such as Turkana, where the teacher-to-student ratio is 1:92 (Mutisya, 2020) and in the informal settlements where facilities are rare to come by. Overcrowding is among academic issues cited even in developed countries such as the United States of America in the recent past (National Center for Education Statistics, 2001).

In Kenya, overcrowding in classrooms traces to 2003 when the NARC government introduced free primary education. In the hope of the Kenyan government, all Kenyans would get basic education, thus abolishing school fees in public primary schools (Simiyu, 2019). This provision saw increased enrollment in public primary schools by 1.3 million learners(Mutisya, 2020). Crowding is also common in urban schools near informal settlements where the number of available schools is too low to support the learners' population in the area. In addition, the overcrowding in classrooms extends to low-paying private schools and community schools (Wanjihia, et al., 2021). Nishimura (2019) expressed that public schools in Kajiado County are overcrowded with insufficient learning facilities. Amunga, Were, andAshioya (2020) explain that large class sizes, lack of facilities, and understaffing were among the areas that needed attention if CBC is to see the light of day.

\subsection{Suggestions for Solving the Overcrowding Problem in Public Primary Schools}

The United States of America introduced charter schools to solve the issue of overcrowding in public schools. This dynamic changed after Minnesota passed laws leading to establishment of charters (National Center for Education Statistics, 2021). In these arrangements, various institutions, including churches and community schools offered education without charges of charter schools or taxation. Certified teachers, Community groups, Universities, non-profit groups, corporations, or even the government would introduce these school (National Center for Education Statistics, 2021). In addition, the state's law offered that anyone presenting charter schools had to first obtain authorization to leave the school district's city or shape depending on the structure of laws regulating the institution (Charter Schools Program State Educational Agencies, 2019).

Charter school models achieved innumerable successes in the United States in the last three decades. Charter schools in the United States skyrocketed leading to high enrolment rates in schools. The new structure enhanced fair competition regarding recruitment in American public and private schools. By 2016, over 7000 charter schools were already in operation and served three million students. Suffice it to say, charter schools challenged status quo of American education system and delivered results that scaled-up options for parents.

In Kenya, the government has been funding private universities to ease congestion in public universities (Nganga, 2011). The approach has seen high enrolment rates and increased intakes of Kenyan students after high school education (Obosi, 2018). According to Obosi (2018), private universities were on the verge of shutting down because students shied away from its expensive fee. However, the moment the government crafted a deal that absorbed Kenyan students through private universities, the institutions opened large spaces for more students in Kenya.

\section{Research Design and Methodology}

This study adopted a concurrent triangulation design, mixing survey data with qualitative data from structured interviews and desk research. This study targetedtwo hundred and three public primary schools in Nairobi County ( $\mathrm{N}=$ 203). The information concerning private schools was gathered from original publications. For the sake of this paper, the 
interest was on the student population in private-public schools to offer a balance that would help the government reduce congestion in public primary schools. The study sampled 30 schools which translate to 15\% of the entire population. A 10$30 \%$ sample is sufficient to represent the target population. Sampled schools in the selected four sub-counties would mean the whole study (Ansar, Astin, Arifin, \& Yudith, 2017). Study tools were questionnaires for teachers, lesson observation checklists, and document analysis guide for analyzing professional documents used by the teachers to implement the competency-based curriculum in science learning areas. Observation checklists were used for observing lessons in science learning areas (environmental activities). Questionnaires are vital tools for collecting authentic information about the respondents and are helpful and time-saving when collecting data in situations where many participants are involved (Akinci \& Saunders, 2015; American Community Survey, 2017).

\section{Findings of the Study: Public Primary Schools Are Overcrowded with Large Class Sizes}

The study sought to find out the average number of learners enrolled per CBC stream. Results were as presented in Table 1. This represents the number of learners in science-based classes for every Grade 3 and Grade 4 teachers who participated in the study. The data from the survey were analyzed and the results were as in Table 1.

\begin{tabular}{|c|c|c|}
\hline Class Enrolment & Frequencies & Percentages (\%) \\
\hline 39 and below & 0 & 0.00 \\
\hline $40-59$ & 51 & 17.65 \\
\hline $60-79$ & 146 & 50.52 \\
\hline $80-99$ & 78 & 26.90 \\
\hline 100 and above & 14 & 4.81 \\
\hline Total & 289 & 100.0 \\
\hline
\end{tabular}

Table 1: Distribution of Learners by Class Enrolment

$\mathrm{N}=289$

From Table 1, no class had less than 39 learners while 51 classes (17.65\%) had between 40-59 learners; 146 (50.52\%) had 60-79 learners; 78 (26.90\%) had 80-99 learners,14 (4.85\%) and had a total number of learners up to 100 and above. The Table reveals that, more than $95 \%$ of the study sample had between 40-99 learners per class which could imply the employment of teacher-centric methods in lesson delivery and to great extent promotion of passive learning. Therefore, this study's reality also alters the learner-centered approach recommended in CBC implementation (Kenya Yearbook Editorial Board, 2019).In this case, whether a teacher had undergone CBC training or not, the situation presents a challenge that deters them from adopting learner-centered methodologies recommended in the CBC implementation plan. A continuation of the status quo observed if allowed, would tamper with effective implementation of the welldesigned Competency-Based Curriculum.

\subsection{Challenges Associated with Overcrowded Classrooms}

Overcrowding and crumbling of buildings are common in schools within shanties. Graham (2009) offers that schools burdened with high population experience wear and tear of facilities at high rates. From Muthusamy (2015), 24\% of all publicschools in the United States reported a building below the standard condition and $43 \%$ had at least an unsatisfactory environmental factor (Schiavi Leasing Corporation, 2020). These issues also correlated with enrolment rates (Orina, 2020). Other problems reported in overcrowded schools include poor sanitation, plumbing-related issues, foundations, ventilation, electric power, and leaking roofs (Schiavi Leasing Corporation, 2020).

Teachers in public schools also reported disruption of the class session in an overcrowded classroom. Indiscipline in overcrowded public primary schools was frequently observed with teachers indicating that class control was a challenge (Byrne, 2009). After observing students in crisis, teachers had resigned from their teaching job because they found themselves helpless in solving the problem of indiscipline and overcrowding in classrooms (Muthusamy, 2015). In addition, teachers reported that learners in overcrowded classes were defiant and threatened the safety and wellbeing of teachers (Byrne, 2009). Some teachers resign on these grounds, while others consider quitting based on the problems. Therefore, overcrowded classrooms present chaotic situations where maximizing learning outcomes is impractical for teachers. In such cases even the most equipped teacher finds he/she unable to efficiently implement the curriculum.

Victoria State Government (2013) observes that overcrowded classes also exposed insufficient learning materials problems in public schools, reducing chances of active participation by learners. In addition, many learners overwhelm teachers who then transfer the problems to parents (Orina, 2020). The same challenges of crowding made teachers to misrepresent the CBC implementation plan in the name of improvising to accommodate large classrooms (Oduor, 2020).

In Kenya, Teachers union such as KNUT and KUSNET also expressed overcrowding as a significant challenge facing CBC in the implementation stage (KNUT, 2019). From the issues raised such as overcrowded classrooms, understaffing in schools and insufficient learning spaces are apparent problems that would suffocate the implementation of CBC in its early stages.According to Ribeiro et al. (2016), teachers had slim chances for making individual assessments in overcrowded classes, which has often characterized public schools in Sub-Saharan Africa. Such a situation parallels the $\mathrm{CBC}$ requirements of more miniature manageable classes intended to enable active learner-centered learning. 


\subsection{Challenges Faced in Implementing Competency-Based Curriculum in Science Areas in the Context of Overcrowded} Classrooms

The teachers were asked to indicate challenges they face in implementing CBC in science learning areas. Figure 1 is a summary of their responses.

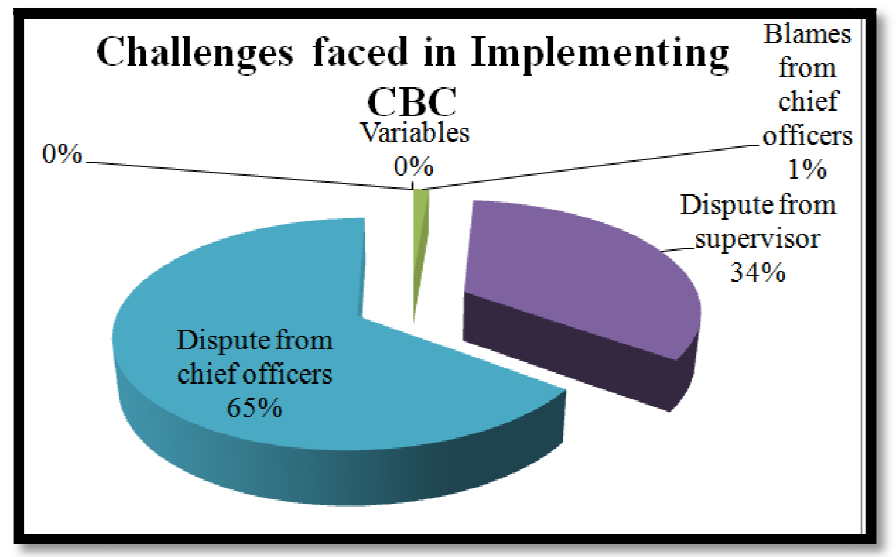

Figure 1: Challenges Teachers Face While Implementing Science Learning Areas in CBC

From figure 1challenges included inadequate technology infrastructure (29\%), unclear assessment methods (27\%), and large classes (23\%). Lack of support from parents (13\%) and, financial constraints in schools (8\%) also posed significant challenges for teachers and their learners.These problems combined have given teachers a hard time implementing the new syllabus. Even where a teacher is well versed with technology and gadgets are available, it is a very difficult task to offer good I.T. devices for learning in overcrowded classes with limited space for learning and teacher movement. This when coupled with understaffing in schools, low teacher-to-learner ratio and a high workload for teachers only compound the challenges. The finding concurs with the thoughts of head teacher one (HT1) and Curriculum Support Officer 9 (CSO 9) who had the following to say:

'Compared to all challenges that we face in the implementation of this curriculum; my teachers struggle more with large classes. If only these classes would be split, our problems would be half solved and my teachers, with the exception of one or two, would all be good to go.' (HT1, 3/11/2020)

'Teachers have had to negotiate many challenges in this new curriculum but the mother of them all is large unmanageable classes where teachers lack space to conduct learning. These teething problems will take time to be resolved. Meanwhile teachers will have to persevere.' (CSO 9, 28/1/2021)

This finding agrees with the findings of a study done by Amunga, Were \&Ashioya (2020) whose results indicated that outsized classes were a significant challenge to implementing CBC in Kenya. This challenge, especially when coupled with understaffing and an insufficient number of classrooms in schools, negates the plan of CBC to have learner-centered learning with individualized teacher attention for every child.

Even when well-versed with learner-centered learning methods, the teacher would shy away from them due to lack of time, limited work space and unmanageable class sizes. The teacher then adopts teacher centered methodologies like the lecture method. Such methodologies are less taxing and are teacher friendly in the prevailing circumstances. The loser is the learner whose individual services, the power to construct knowledge and the right to be involved in the learning process are denied.

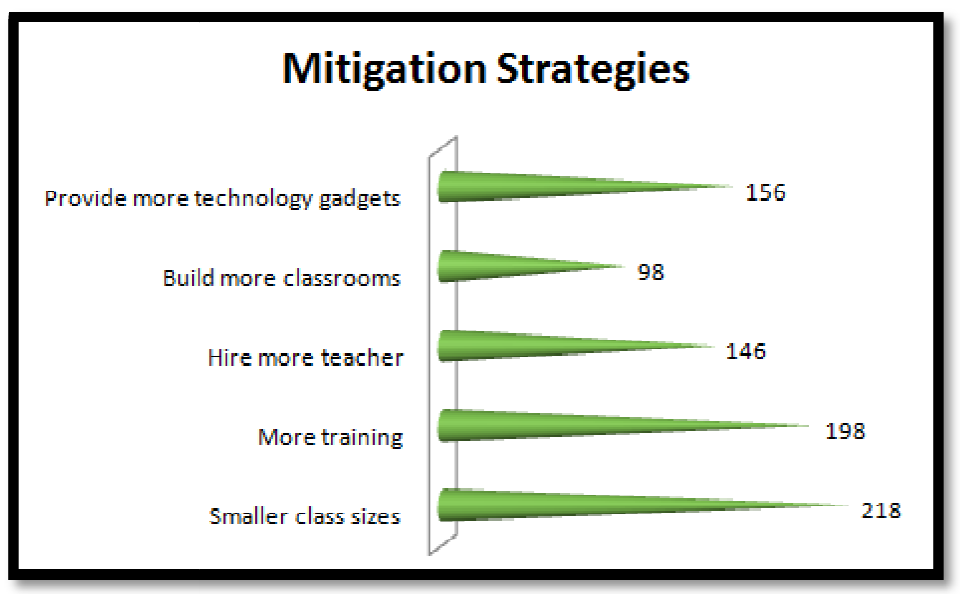

Figure 2:Mitigation Strategies

When asked mitigation strategies for the challenges, teachers listed down several methods top of which was about splitting classes into smaller units. Their suggestions include building more classrooms to provide more space for learning; 
hiring more teachers to boost teacher learner ratio and splitting classes into smaller ones. All these are strategies for ensuring that a teacher handles a smaller class size which in turn enables the use of learner centered methodologies.

\subsection{Private Schools' Enrolments}

While public schools face overcrowding, low-cost private schools have experienced low enrollment rates, especially after the outbreak of the Covid-19 pandemic. The economic pressure brought by the pandemic has led to partial closure, teachers' retrenchment, and in some cases, permanent closure of various private schools that could not afford to adapt to the economic situations (Alam, Tiwari, \& UNICEF, 2021). According to McCluskey (2021), 132 private schools at district levels were closed permanently and threaten national schools. In addition,5\% of schools in Kenya are privately owned (Dahir, 2020). According to Dahir (2020), private schools in Kenya also shut down even after offering online learning requirements. Ideally, this construction willbecome wasteland after the closure while public schools are still overcrowded.

\section{Conclusion}

Overcrowded classrooms, understaffing in schools and insufficient learning space in terms of additional classrooms are problems that would suffocate the implementation of $\mathrm{CBC}$ in its early stages unless tackled by the government of Kenya and other key stakeholders.

Private Schools still have space that can absorb part of the excess population in public schools. However, the study demonstrated that low-cost private schools are closing down after the corona pandemic. In addition, the same schools are retrenching teachers while public schools are in dire need of teachers.

Other problems associated with the shortage of infrastructure are the consequences of a large population and shortage of funds. If the overcrowding problem would be managed in public schools, it will open an entry to the successful implementation of CBC.

\section{Recommendation}

\subsection{Introduce Charter Schools in Kenya}

Charter Schools are public schools that operate independently with the freedom to design their classrooms to meet learners' needs (Charter Schools, 2021). These institutions operate under the charter school's authorizer, who in many cases are non-profit organizations, universities, government agencies, and other stakeholders to hold them accountable in meeting the standards sets in the charter (Charter Schools Program State Educational Agencies , 2019). Charter schools have unique operations and accommodate various sites, including churches, libraries, and places of work. (Charter Schools, 2021). For the sake of Kenya, religious organizations' sites that are predominantly populated one day in a week may work as a starting point. In this case, willing churches may offer their halls for specified studies within the community and allow classes to proceed. The beauty of charter schools is that they can accommodate appropriate times according to their designs.

\subsection{Fund Private Schools to Accommodate the Overflow in Public Institutions}

As demonstrated earlier, low-cost private schools are shutting down, leaving their structures unutilized. While these classes and teachers go unutilized public schools are overcrowded, and the numbers overwhelm teachers. From the Trans-theoretical Model, excess in public schools would be transferred to private schools like it was used to solve the homelessness problem (Campbell, 2006). The private primary schools have teachers and spaces, as the government funds free primary schools' part of the funding can be allocated to private schools on conditions that they accommodate learners in proportion to government funding. This approach will make a case of solving three problems. This approachhas worked with universities and colleges and cansolve the overcrowding problem, increase teacher to learner ratio; and increase infrastructure for learning hence upgrade learning conditions in Kenyan primary schools.

\subsection{Radical Heavy Investment in Public School Infrastructure Accompanied by Mass Teacher Recruitment}

The Competency based curriculum would thrive in a learning environment with high teacher learner ratio. This calls for the splitting of all large classesinto smaller bits. This scenario would work well if the Kenyan M.o.E buys political good will to focus more investments to the education sector. The country needs to channel money to public primary school for construction of more classrooms and other learning spaces. This should be accompanied by hiring more and more teachers to improve teacher to learner ratio.

\section{References}

i. Akinci, C., \& Saunders, M. N. (2015). Using questionnaire survey for within-organization HRD research. In M. N. Saunders, \& P. Tosey (Eds.), Handbook for research methods on HRD (pp. 353-356). Chentelham: Edward Elgar.

ii. Alam, A., Tiwari, P., \& UNICEF. (2021). implications of COVID-19 for Low-cost Private Schools. UNICEF, Office of Global Insight and Policy. Global Insight Media. Retrieved from https://www.unicef.org/globalinsight/media/1581/file/UNICEF_Global_Insight_Implications_covid-19_Lowcost_Private_Schools_2021.pdf

iii. American Community Survey. (2017, August). Accuracy of the 2017 Survey Data. Retrieved January 29, 2020, from United States Census Government Programmes. 
iv. Amunga, J., Were, D., \&Ashioya, I. (2020). The teacher-parent nexus in competency-based curriculum success equation in Kenya. International Journal of Educational Administration and Policy Studies, 12(1), 60-76.

v. Ansar, M., Astin, L., Arifin, S., \&Yudith, D. J. (2017). The Influence of School Culture on the Performance of High School English Teachers in Gorontalo Province. International Journal of Education and Research, 40.

vi. Byrne, M. (2009). An investigation into the challenges teachers faces when teaching. Edith Cowan University, Faculty of Education and Arts. Texas: Research Online. Retrieved from https://ro.ecu.edu.au/theses/1835/

vii. Campbell, R. D. (2006). The Tran theoretical Model: A Theoretical Application to Homelessness. Grand Valley State University, Social Work Commons. Valey: Graduate Research and Creative Practice at ScholarWork. Retrieved from https://scholarworks.gvsu.edu/cgi/viewcontent.cgi?article=1642\&context=theses

viii. Charter Schools. (2021). Reimagining Education: One school, one classroom, one student at a time. Retrieved from Public Charter Schools: https://www.publiccharters.org/about-charter-schools/what-charter-school

ix. Charter Schools Program State Educational Agencies. (2019, June 21). Legislation, Regulations, and Guidance. Retrieved from U.S. Department of Education: https://www2.ed.gov/programs/charter/legislation.html

x. Dahir, L. A. (2020, August 5). Kenya's Unusual Solution to the School Problem: Cancel the Year and Start Over. New York Times. Retrieved from https://www.nytimes.com/2020/08/05/world/africa/Kenya-cancels-schoolyear-coronavirus.html

xi. Education Commission of the States. (2020). What Are the Teacher-to-Student Ratio Requirements and Class Size Maximums for Grades K-3? 50-State Comparison: State K-3 Policies. Denver: Education Commission of the States.

xii. Fernando, S., \&Marikar, F. (2017). Constructivist teaching/learning theory of participatory teaching methods. Journal of Curriculum and Teaching, 6 (1).

xiii. Graham, E. (2009). Public School Education - The Case for Reduced Class Size: Why the Present Class Size is Not Working and What Can We Do About It? Argosy University, Department of Education. New York: The Education Resources Information Center. Retrieved from https://files.eric.ed.gov/fulltext/ED503690.pdf

xiv. Hachem, H., \& Mayor, P. (2019, October 4). Overcrowding in Schools: Why is it a Huge Issue? Dearborn, pp. 3-5.

xv. Kenya Yearbook Editorial Board. (2019, July 20). Teacher Shortage, Poor Infrastructure Main Challenges Facing Implementation Of CBC. Kenya News Agency, pp. 13052-02. Retrieved from https://www.kenyanews.go.ke/13052-2/

xvi. KNUT. (2019). Teacher Preparedness for the Implementation of the Competency-Based Curriculum in the PrePrimary and Lower primary grades in Kenya. Nairobi: Kenya National Union of Teachers.

xvii. McCluskey, N. (2021, April 15). If All Private Schools Permanently Closed by COVID Were a School District, It Would Be Among the Nation's Biggest. Should We Worry? CATO Institute. Retrieved from https://www.cato.org/blog/were-private-schools-shuttered-due-covid-district-they-would-be

xviii. Muriithi, T., Mwania, J. M., \&Mwinzi, J. (2016). The influence of finacial resources in the intergration of the Nationa goals of education. Internationla Journal of Education and Research, 4 (9).

xix. Muthusamy, N. (2015). Teacher's Experience with Overcrowded Classrooms in Mainstream Schools. University of KwaZulu-Natal, Education. Victoria: Research Space. Retrieved from https://researchspace.ukzn.ac.za/bitstream/handle/10413/12646/Muthusamy_Nirashnee_2015.pdf?sequence $=1 \&$ isAllowed $=\mathrm{y}$

xx. Mutisya, M. (2020, February 25). Some Kenyan schools are dangerously overcrowded. What must be done. African Population and Health Research Center, p. 7452.

xxi. National Center for Education Statistics. (2001). Conditions of America's Public Schools facilities. Washington: National Post Secondary Education Cooperative.

xxii. National Center for Education Statistics. (2021). Public Charter School Enrollment. NCES, Preprimary, Elementary, and Secondary Education. Washington DC: U.S. Department of Education. Retrieved from https://nces.ed.gov/programs/coe/indicator/cgb

xxiii. Nganga, G. (2011, December 18). KENYA: Universities in talks with private investors. University World News. Retrieved from https://www.universityworldnews.com/post.php?story=20111216172218651

xxiv. Nishimura, M. (2019). Community participation in school governance: The Maasai community in Kenya. 47(4), 393-412. doi:10.1007/s11125-018-9439-8

xxv. Obosi, J. (2018). Public-Private Partnerships as A Redistributive Strategy in University Education in Kenya. Ph.D. Thesis, University of Nairobi, Department of Education Foundations, Nairobi. Retrieved from https://www.researchgate.net/publication/328416236_PUBLIC_PRIVATE_PARTNERSHIPS_AS_A_REDISTRIBU TIVE_STRATEGY_IN_UNIVERSITY_EDUCATION_IN_KENYA

xxvi. Oduor, A. (2020, February 17). A year later, teachers have yet to master the new system. The standard Newspaper, pp. 4-5.

xxvii. Orina, W. A. (2020). The expanded role of parents in Kenyan education thwarting the new Competency-Based Curriculum plan. International Journal of Innovative Research and Development, 9(10), 74-91.

xxviii. Prochaska, J. O., \&Velicer, W. F. (1997). The transtheoretical model of health behavior change. Health Promotion, 12(1), 38-48. doi:10.4278/0890-1171-12.1.38. PMID: 10170434.

xxix. Ribeiro, S., Mota, N. B., Fernandes, d. R., Deslandes, A. C., Brockington, G., \&Copelli, M. (2016). Physiology and assessment as low-hanging fruit for an education overhaul. Prospects (00331538), 46(2), 249-264. 
xxx. Schiavi Leasing Corporation. (2020, January 27). Overcrowded Classrooms: Your Solution to A Growing Concern. Retrieved from Vanguard Modular Building Systems: https://vanguardmodular.com/blog/overcrowded-classroom/

xxxi. Simiyu, C. N. (2019). The Challenges of Free Primary Education Implementation in Primary Schools in Bungoma County, Kenya. International Journal of Scientific Research and Management, 7(1), 71-78. doi:10.18535/ijsrm/v7i1.el02

xxxii. Victoria State Government. (2013). Victoria's compulsory Child Safe Standards. Department of Health and Human service. Retrieved from \&lt;https://providers.dhhs.vic.gov.au/child-safe-standards\&gt;

xxxiii. Wanjihia, V. W., Chepkirui, F., Hitachi, M., Muniu, E., Nyandieka, L., Ndemwa, P., \&Wekesa, E. (2021). The Association between Nutritional Knowledge, Socio-Economic Status of Caregivers and Stunting of Children Under 5 Years in Kwale County of Kenya: A Baseline Survey. Austin Journal of Nutrition \& Metabolism, 8(2), 2141-53. doi:10.26420/austinjnutrmetab.2021.1105

xxxiv. Williams, M. K. (2017). John Dewey in the 21st Century. Journal of Inquiry \& Action in Education, 9 (1).

xxxv. Wilson, P., Dario, C., \&Simar, L. (2018). Central limits theorem for conditional efficiency measures and tests of the separability condition in nonparametric two-stage production models. The Econometrics Journal.

xxxvi. Yi, Y. J. (2020). The current state of Homelessness in Japan. Osaka: The Borgen project organization. 